\title{
LOCAL SMART DC NETWORKS AND DISTRIBUTED STORAGE FOR REDUCING AND SHIFTING PEAK LOAD
}

\author{
Simon Daniel \\ Moixa Technology - UK \\ simon@moixaenergy.com
}

\author{
Spyros Skarvelis-Kazakos \\ University of Greenwich - UK \\ S.Skarvelis-Kazakos@greenwich.ac.uk
}

\author{
Priyanka Jain \\ Cambridge University - UK \\ priyankaj@gmail.com
}

\begin{abstract}
This paper examines theoretical models of smart distributed storage devices located at customer premises for powering local DC lighting and electronic loads, and explores enabled business models and field data from deployments of example Smart DC/Storage systems by Moixa Technology.
\end{abstract}

\section{INTRODUCTION}

Annual electricity demand in UK in 2010 was 328 TWh of which $36 \%$ was household electricity demand of 119 TWh. Of this, the demand for domestic electrical appliances in households was about 85 TWh [1].

Demand for electricity from domestic electrical appliances has grown rapidly over the past 40 years (average 3\% per year) [2]. The total number of appliances used in homes is projected to increase by 2020 , but overall electricity demand is estimated to decline with guaranteed policies for capping domestic appliance use and adoption of high efficiency products [3]. Table 1 below is an estimate of the annual demand from domestic electrical appliances in 2009 and 2020 [3].

85.3 TWh per annum translate to $233 \mathrm{GWh} /$ day or 9 KWh/day per household of electricity demand from household appliances in UK.

Table 1 UK domestic electrical appliance end-use 2009 [1], 2020 [3] (minus heating and hot water)

\begin{tabular}{|c|c|c|c|}
\hline $\begin{array}{c}\text { Domestic } \\
\text { Electrical } \\
\text { Appliance }\end{array}$ & $\begin{array}{c}\text { 2009 Total } \\
\text { load, TWh/yr }\end{array}$ & $\begin{array}{c}\text { 2020 Total } \\
\text { load, } \\
\text { TWh/yr, } \\
\text { Reference } \\
\text { Scenario }\end{array}$ & $\begin{array}{c}\text { 2020 Total } \\
\text { load, } \\
\text { TWh/yr } \\
\text { Policy } \\
\text { Scenario }\end{array}$ \\
\hline Audiovisual & $20.8(24 \%)$ & 21.5 & 16.7 \\
\hline Lighting & $15.8(19 \%)$ & 11.9 & 10.6 \\
\hline ICT & $6.5(8 \%)$ & 6.9 & 4.5 \\
\hline $\begin{array}{c}\text { Cold } \\
\text { Appliances }\end{array}$ & $14.4(17 \%)$ & 10.6 & 9.8 \\
\hline $\begin{array}{c}\text { Washing/ } \\
\text { Drying }\end{array}$ & $14.2(17 \%)$ & 15.5 & 14.5 \\
\hline $\begin{array}{c}\text { Cooking } \\
\text { appliances }\end{array}$ & $13.6(16 \%)$ & 13.6 & 12.2 \\
\hline Total & $\begin{array}{c}\mathbf{8 5 . 3} \\
\mathbf{T W h} / \mathbf{y r}\end{array}$ & $\begin{array}{c}\mathbf{8 0} \\
\mathbf{T W h} / \mathbf{y r}\end{array}$ & $\begin{array}{c}\mathbf{6 8 . 3} \\
\mathbf{T W h} / \mathbf{y r}\end{array}$ \\
\hline
\end{tabular}

Most traditional appliances require supply of alternating current (AC). However, latest devices in consumer electronics, lighting, and ICT are low wattage devices that require or are likely to require direct current (DC) supply of electricity in the future. All ICT (i.e. PCs -3.9 TWh, laptops - $0.7 \mathrm{TWh}$, monitors $-1.5 \mathrm{TWh}$, and imaging -0.4 TWh) used in homes today is $100 \%$ DC. Lighting would be $100 \%$ DC when all homes switch to LED lighting. Most consumer electronics (PSUs - 5 TWh, set top boxes - 3.6 TWh, videos, DVDs $-3.2 \mathrm{TWh}$, game consoles $-0.6 \mathrm{TWh})$ are $100 \%$ DC and TVs (8.3 TWh) are gradually becoming DC with the market adoption of LED TVs. Other devices such as DC fridges and DC pumps and motors in washing appliances are also becoming available. Most DC internal devices are currently accompanied by inverters that convert AC grid supply into DC supply.

From highlighted rows in Table 1 (audiovisual, lighting and ICT), the share of DC internal devices is estimated as 50\% of current $(43 \mathrm{TWh})$ and $50 \%$ of future $(40 \mathrm{TWh}$ in reference scenario) household appliance load. This paper focuses on the management of DC household appliance loads to reduce peak load electricity usage in the UK.

\section{REPRESENTS A HIGH SHARE OF PEAK HOUSEHOLD ELECTRICITY DEMAND}

Figure 1 and Table 2 describe the average hourly breakdown of the $9 \mathrm{KWh}$ daily electricity demand for appliances for a typical UK household [4].

$42 \%$ of appliance load $(3.8 \mathrm{KWh})$ falls during the peak period (defined here as $4 \mathrm{PM}-10 \mathrm{PM})$. DC devices constitute $57 \%$ of this load $(2.2 \mathrm{KWh})$ [4].

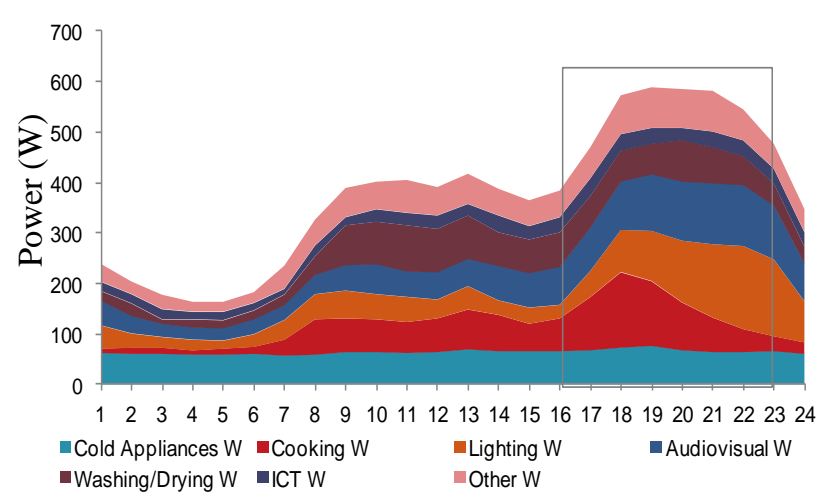

Fig 1 Average hourly demand profile for appliances and lighting for a typical household in the UK, 2010 [4] 
Table 2 Peak load composition of UK domestic electrical appliance end-use 2010 [4].

\begin{tabular}{|c|c|c|c|}
\hline $\begin{array}{l}\text { Type } \\
\text { of } \\
\text { load }\end{array}$ & $\begin{array}{l}\text { Domestic } \\
\text { Electrical } \\
\text { Appliance }\end{array}$ & $\begin{array}{c}\text { Average } \\
\text { daily }(24 h) \\
\text { single } \\
\text { household } \\
\text { load, KWh }\end{array}$ & $\begin{array}{c}\text { Peak load } \\
\text { average single } \\
\text { household } \\
\text { (4 PM-10 PM), } \\
\text { KWh }\end{array}$ \\
\hline \multirow{4}{*}{ DC } & Audiovisual & 1.6 & $0.8(21 \%)$ \\
\hline & Lighting & 1.5 & $0.8(21 \%)$ \\
\hline & ICT & 0.6 & $0.2(5 \%)$ \\
\hline & Other DC & 0.9 & $0.4(11 \%)$ \\
\hline \multirow{4}{*}{$\mathbf{A C}$} & $\begin{array}{l}\text { Washing/ } \\
\text { Drying }\end{array}$ & 1.3 & $0.4(11 \%)$ \\
\hline & $\begin{array}{c}\text { Cold } \\
\text { Appliances }\end{array}$ & 1.6 & $0.5(13 \%)$ \\
\hline & Cooking & 1.3 & $0.6(16 \%)$ \\
\hline & Other AC & 0.2 & $0.1(3 \%)$ \\
\hline \multicolumn{2}{|r|}{ Total } & $\begin{array}{c}9 \mathrm{KWh} / \\
\text { day/ home }\end{array}$ & $\begin{array}{l}\text { 3.8 KWh peak } \\
\text { load/day/home }\end{array}$ \\
\hline
\end{tabular}

The domestic sector is considered to have the highest potential for peak shifting in the evening among all other sectors, currently and in the future - regardless of whether summer or winter.

Summer and Winter evening peaks (peak here defined as 4 PM - 7 PM by [1],[5],[6],[7]) are currently estimated as 35 GW and $54 \mathrm{GW}$ respectively [5]. There is a limited match, however, in the household sector between what contributes to peak (i.e. mainly DC loads such as lighting, TV, consumer electronics etc.) and what households may be willing to shift voluntarily which appears to be mainly wet appliances [6]. Current DSM studies focus solely on AC devices (including heating) to shift peak household appliances load to off-peak hours [5],[8],[9]. It is estimated that these devices add up to $9 \mathrm{GW}$ of shiftable load in winter evening and $6 \mathrm{GW}$ of shiftable load in summer evening in 2010 (on an average $7.5 \mathrm{GW}$ daily between 4PM - 7 PM) [5].

Current estimations from other papers are also similar in that only about a quarter to a fifth of household appliances load is price responsive [8]. In a 2010 DSR report, Ofgem assumed only $5-15 \%$ peak-shift potential in the household sector [10] (i.e. 5 TWh annually from Fig. 1).

DC loads such as lighting, computing and other electronics, represent a bigger share of peak load. This paper establishes that it is possible to shift all household DC load off-peak in the long run. This translates into a reduction opportunity of over $4.68 \mathrm{GW}$ daily and $15 \mathrm{TWh}$ annually between $4 \mathrm{PM}$ and 10 PM (i.e. observed peak in appliance load in Fig. 1).

\section{PROPOSED ASSURED SOLUTION TO SHIFT DC ELECTRICITY LOAD OFF-PEAK}

Moixa Technology has developed a hybrid system with smart DC home hub and smart batteries (e.g. $1 \mathrm{kWh}+$, LiFE or NiMH battery packs re-used from EV). The battery is charging during solar hours or off-peak via smart meter trigger and powers household DC lighting and electronics load during peak hours. The Smart DC home is a concept to replace maximum possible household $\mathrm{AC}$ appliances with their efficient DC counterparts, which can then be charged by a DC network supply at home - thus enabling efficiency gains and reducing AC-DC conversion losses (see Fig. 4).

Key characteristics of the Moixa hybrid system:

1. Ensures lighting, plausible electronics and ICT is switched to DC efficient devices

2. $1 \mathrm{kWh}$ distributed storage asset in households

3. Free battery charging using free solar or off-peak price

4. Batteries available in aggregate for scheduled DSM

Key benefits (theoretical) of Moixa hybrid system in a single household:

1. $2 \mathrm{kWh}$ load shifted off-peak: $1 \mathrm{kWh}$ load shifted from peak to solar hours by using battery, $1 \mathrm{kWh}$ load reduced through efficiency and conversion savings

2. $0.5 \mathrm{kWh}$ load reduced during off-peak hours through efficiency and conversion savings

3. Overall $1.5 \mathrm{kWh}$ of electricity saving during the day

4. $190 \mathrm{~W}$ minimum peak power shaving per home during 4 PM - 10 PM

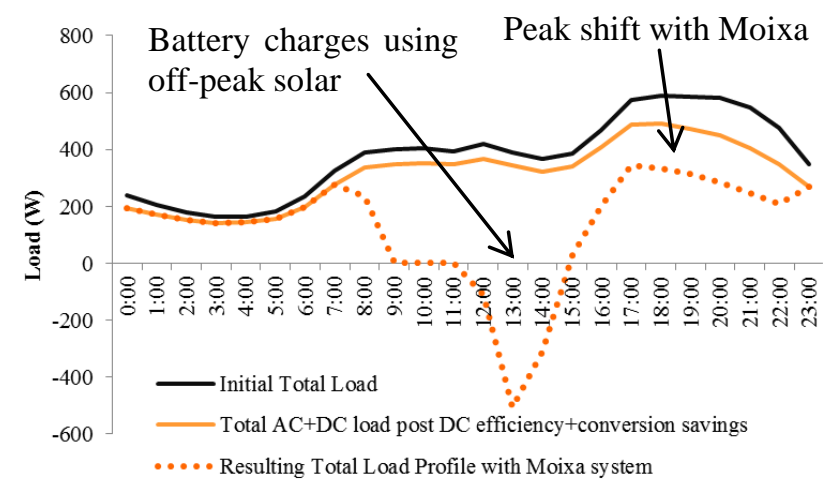

Fig 2 Peak shift with Moixa system

\section{CASE STUDY 1: 5\% PENETRATION OF MOIXA SYSTEM IN A TYPICAL DISTRIBUTION CLUSTER}

A case study was modelled with the following assumptions:

1. Moixa system installed in 1000 homes in a typical distribution cluster in UK with 18432 homes (Figure 3) $[11],[12]$

2. $80 \%$ lighting, $80 \%$ ICT, $80 \%$ audiovisual switched to DC devices 
3. $1 \mathrm{KW}$ battery capacity added per home in 1000 homes

4. No solar/ renewable generation. Battery charges during night (with off-peak tarriff)

5. Assumed $80 \%$ efficiency savings on LED, $10 \%$ on rest; 14\% AC-DC conversion savings

6. Annual peak load of network: $26 \mathrm{GWh}$

7. Annual total load of network: $60 \mathrm{GWh}$

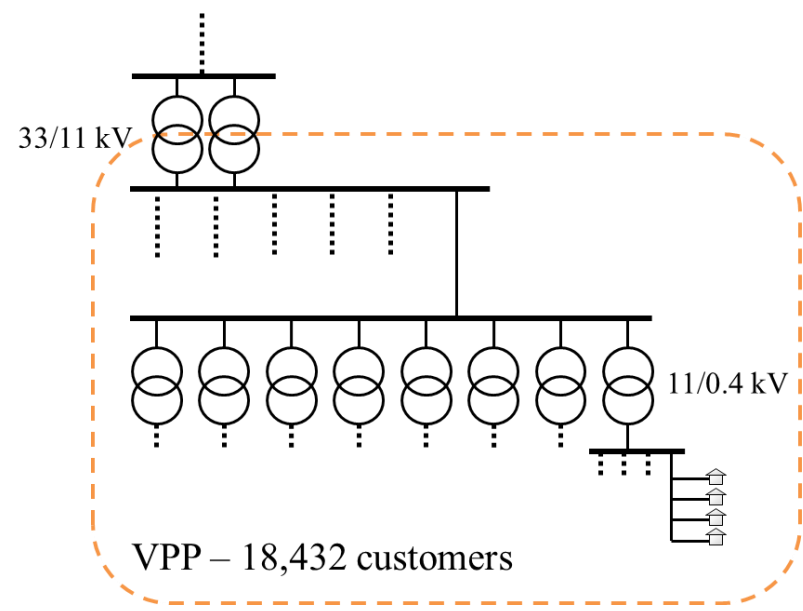

Fig 3 UK Generic Distribution Network (18432 domestic customers) [11],[12]

The outcome of the model can be summarised as follows:

- Total annual peak load shifted off-peak: 665 MWh (2.56\%)

- Total annual savings on electricity: $\mathbf{5 5 0}$ MWh (1\%)

\section{CASE STUDY 2: BENEFITS OF MOIXA SYSTEMS DEPLOYED IN LARGE SCALE IN THE UK}

Table 3 describes the daily benefits of deploying Moixa systems in 1, 10 and 26 million households (assuming similar values of \% DC and efficiency savings as in Case Study 1).

Table 3 Daily benefits of deploying Moixa systems at large scale in UK

\begin{tabular}{|c|c|c|c|}
\hline $\begin{array}{c}\text { \# Households } \\
\text { with Moixa } \\
\text { systems }\end{array}$ & $\begin{array}{c}\text { Minimum } \\
\text { daily load } \\
\text { peak } \\
\text { reduction * }\end{array}$ & $\begin{array}{c}\text { Daily 4-10 } \\
\text { PM Peak } \\
\text { energy } \\
\text { saving }\end{array}$ & $\begin{array}{c}\text { Daily } \\
\text { energy } \\
\text { saving }\end{array}$ \\
\hline $\mathbf{1}$ & $0.19 \mathrm{~kW}$ & $1.8 \mathrm{kWh}$ & $1.5 \mathrm{kWh}$ \\
\hline $\mathbf{1 0 0 0}$ & $0.19 \mathrm{MW}$ & $1.8 \mathrm{MWh}$ & $1.5 \mathrm{MWh}$ \\
\hline $\mathbf{1 ~ M}$ & $0.19 \mathrm{GW}$ & $1.8 \mathrm{GWh}$ & $1.5 \mathrm{GWh}$ \\
\hline $\mathbf{1 0 ~ M}$ & $1.9 \mathrm{GW}$ & $18 \mathrm{GWh}$ & $15 \mathrm{GWh}$ \\
\hline $\mathbf{2 6 ~ M}$ & $4.68 \mathrm{GW}$ & $47 \mathrm{GWh}$ & $41.6 \mathrm{GWh}$ \\
\hline * Compared to $7.5 \mathrm{GW}$ of AC peak load considered shift- \\
able as discussed above
\end{tabular}

Moixa system deployed at such large scales can bring immense benefits and stability to the electricity supply network. Table 4 discusses annual system benefits and savings generated by different players in the electricity value chain by deploying $1 \mathrm{M}$ Moixa systems in the UK.

Table 4 is an indicative view on the benefits of the storage element in aggregate. In [13], a potential $£ 0.12$ bn in 2020 rising to $£ 2$ bn in 2030 and $£ 10$ bn in 2050 is modelled for

Table 4 Estimate of annual savings generated with 1 million Moixa systems in UK households

\begin{tabular}{|c|c|c|c|}
\hline & Benefits & Annual value & Assumptions \\
\hline Consumers & $\begin{array}{l}\text { - } \mathbf{5 5 0} \mathbf{~ G W h} \text { annual reduction in } \\
\text { electricity usage } \\
\text { - } \mathbf{1 ~ G W} \text { battery storage asset - } \\
\text { security }\end{array}$ & $£ 98 \mathrm{M}$ & $\begin{array}{l}\text { Dual Tariff: } 7 p \text { off-peak, } \\
16 p \text { peak }\end{array}$ \\
\hline DNOs & $\begin{array}{l}\text { - } \mathbf{6 6 5} \text { GWh load shifted off- } \\
\text { peak annually } \\
\text { - Distribution CAPEX savings }\end{array}$ & $£ 63 \mathrm{M}$ & $\begin{array}{l}\text { Distribution CAPEX saving: } £ 60 / \mathrm{KW} \text {.year of storage } \\
\text { Generation CAPEX saving: } £ 50 / \mathrm{KW} \text {.year of storage } \\
\text { assumed } £ 40 \text { to avoid double counting for peaker } \\
\text { plant saving below [13] }\end{array}$ \\
\hline $\begin{array}{l}\text { System } \\
\text { Operators }\end{array}$ & $\begin{array}{l}\mathbf{1 9 0} \text { MW peaker plant load } \\
\text { reduction } \\
\text { - } 50 \text { MW available for STOR, } \\
\text { FAST etc. }\end{array}$ & $£ 23 \mathrm{M}$ & $\begin{array}{l}\text { Marginalised cost on CCGT peaker plant: } £ 87 / \mathrm{MWh} \\
\text { [14], 7.5\% load factor; } \\
5 \% \text { Moixa systems provide balancing services during } \\
\text { morning peak } \\
£ 43,000 / \mathrm{MW} \text { STOR }[15] \\
£ 50,000 / \mathrm{MW} \text { FAST }[15]\end{array}$ \\
\hline Government & $\begin{array}{ll}\text { - } & \begin{array}{l}\mathbf{3 0 0 , 0 0 0} \text { tons annual } \mathrm{CO}_{2} \\
\text { saving }\end{array} \\
\end{array}$ & $£ 5 \mathrm{M}$ & $\begin{array}{l}500 \mathrm{~g} \mathrm{CO}_{2} / \mathrm{KWh}^{[16]} \\
£ 16 / \text { tonne of } \mathrm{CO}_{2}\end{array}$ \\
\hline \multicolumn{2}{|r|}{ Total System Savings } & $£ 189 \mathrm{M}$ & \\
\hline
\end{tabular}


storage payback (assuming a 10GW deployment). This is compared to the unique aspects of the Moixa system, such as assured peak period reduction, and net impact of energy efficiency reductions being guaranteed from lighting and AC/DC loss avoidance. Some benefits e,g. $£ 100 / \mathrm{kWh}$ per annum for distributed storage [13] vs. bulk ( $£ 50 / \mathrm{kWh})$ also overlap with specific value areas like STOR or peak plant abatement, or wind curtailment.

\section{CONCLUSIONS}

Moixa systems present an opportunity to address the problem of household evening peak demand reduction by enabling overall energy efficiency and energy security. Each Moixa system has the potential to shift $2 \mathrm{kWh}$ of household DC load to off peak period and reduce daily electricity usage by $1.5 \mathrm{kWh}$.

This presents a win-win case for households adopting time of day tariffs/smart meters to use off-peak supply without unrealistic behavioural change. This also creates benefits in aggregate at the utility level and in low voltage and network level where storage and DSM measures are used for grid balancing, or mitigating infrastructure upgrades, wind curtailment or reducing national investment in peak plant capacity. While this paper has estimated an initial annual value for these benefits, further studies and practical system tests are needed to establish the total system value that can be generated through the deployment of this system.

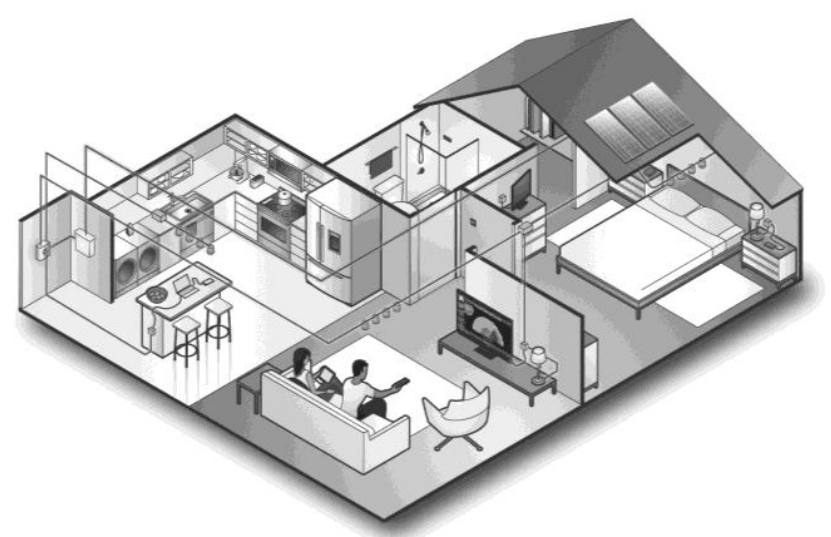

Fig 4 Smart DC home enabled by Moixa system

\section{REFERENCES}

[1] G. Owen, J. Ward, M. Pooley, (2011), “GB Electricity Demand - Context and 2010 baseline data", Sustainability First, Paper 1, pp. 32-33

[2] J. Palmer, I. Cooper, (2011), "Great Britain's housing energy fact file", pp. 28-30

[3] Department for environment, food and rural affairs
(DEFRA), (2009), "Saving energy through better products and appliances"

[4] J. Zimmermann, M. Evans, J. Griggs, N. King, L. Harding, P. Roberts, C. Evans, (2012), "Household Electricity Survey - A study of domestic electrical product usage", Intertek Report, pp. 194

[5] S. Hesmondhalgh, (2012), "GB Electricity Demand 2010, 2025”, Initial Brattle Electricity Demand-Side Model - Scope for Demand Reduction and Flexible Response, Sustainability First, pp. 60, 61, 64, 77

[6] G. Owen, J. Ward, M. Pooley, (2012), “GB Electricity Demand - Realizing the Resource, Paper 3: What demand side services could household customers offer?", Sustainability First, pp. 8,

[7] G. Owen, J. Ward (2010), "Smart Tariffs and Household Demand Response for Great Britain", Sustainability First, pp. 58-59

[8] V. Silva, (2009), "Value of smart appliances in system balancing”, D4.4, Part I of WP4, Smart Domestic Appliances in Sustainable Energy Systems (Smart-A), Imperial College, London, pp. 62

[9] L. Platchkov, M. Pollitt, D. Reiner, I.Shaorshadze, (2010), "Policy Preferences and Energy Saving Measures" Public Opinion Survey - EPRG Working Paper, pp. 40

[10] (2009), "Demand Side Market Participation", IHS Global Insight report for DECC

[11] S. Ingram, S. Probert, and K. Jackson, (2003), "The Impact of Small Scale Embedded Generation on the Operating Parameters of Distribution Networks", Department of Trade and Industry, Contractor: PB Power, Report No. K/EL/00303/04/01

[12] S. Skarvelis-Kazakos, P. Papadopoulos, I. Grau, A. Gerber, L.M. Cipcigan, N. Jenkins and L. Carradore, (2010), "Carbon Optimized Virtual Power Plant with Electric Vehicles", 45th Universities Power Engineering Conference (UPEC), Cardiff, 31 August 3 September 2010

[13] G. Strbac, M. Aunedi, D. Pudjianto, P. Djapic, F. Teng, A. Sturt, D. Jackravut, R. Sansom, V. Yufit, N.Brandon, (2012), "Strategic Assessment of the Role and Value of Energy Storage Systems in the UK Low Carbon Energy Future", Report for the Carbon Trust, Energy Futures Lab, Imperial College EDF UK R\&D Centre, pp. 9

[14] DECC, (2010), "UK Electricity Generation Costs Update", pp.87

[15] G. Hathaway, (2009), "Demand Side Opportunities", National Grid publication

[16] E. Ares, (2012), "Carbon Price support", House of Commons Library 